\title{
ZMIANY W PARADYGMACIE KONIUGACYJNYM OD GOCKIEGO PO WSPÓŁCZESNĄ NIEMCZYZNĘ
}

\author{
MARTA WOŹNICKA \\ Uniwersytet im. Adama Mickiewicza \\ marado@amu.edu.pl
}

\begin{abstract}
Changes in conjugational paradigm from Gothic to modern German
Józef Darski, the author of the "Linguistic Model of Analysis" ("Linguistisches Analysemodell") [1987; 2004] has underlined numerous times in his publications that his model of analysis is only appropriate for the synchronic description of a language. In his considerations Darski pursues precision, which on the one hand enables him to exemplify his model on a number of European languages, namely German, English, French and Polish, and at the same time lets him reach a level of abstraction that guarantees successful application of the mentioned model to research on other languages. Conversely, Michail L. Kotin [2008; 2012] has shown that Darski's model can very well be used for diachronic research.

The article presents the problems of describing the structure of synthetic grammar verb forms in Gothic, Old, Middle and New High German from a synchronic perspective, that is for each of the particular stages of the development of the German language and in Gothic, and from a diachronic perspective, taking into account the historical and comparative aspects, including the relevant language transformations and their role in the forming of the modern paradigm of verb conjugation. The research uses the model of linguistic analysis devised by Józef Darski; however the analysis, was extended by diachronic threads. Since within this article it is impossible to present a complete analysis of the historical language material, the microparadigmas of the indicative and subjunctive moods of both strong and weak verbs were chosen for this purpose.
\end{abstract}

Keywords: Darski, historical morphology, inflection, verb, root (base form), syntactic marker Schlüsselwörter: Darski, historische Morphologie, Flexion, Verb, Stamm, syntaktische Exponenten Słowa kluczowe: Darski, morfologia historyczna, fleksja, czasownik, rdzeń, wykładniki syntaktyczne 


\section{MARTA WOŹNICKA}

Rozpoznanie, iż rozpowszechnione w publikacjach naukowych dotyczących historii języków germańskich, a w szczególności języka niemieckiego, użycie takich pojęć, jak: pień czasownika (Verbalstamm), rdzeń (Wurzel), końcówka fleksyjna (Flexionsendung), fleksja zewnętrzna i wewnętrzna (innere/äußere Flexion), afiks derywacyjny (Derivationsaffix) nie jest ani spójne, ani bezsprzeczne, było głównym motywem podjęcia badań w zakresie tej tematyki. Komplikacji w obszarze terminologicznym, a niejednokrotnie również metodologicznym, można uniknąć, jeśli zostaną zastosowane precyzyjne kryteria analizy. Jako akceptowalne instrumentarium może posłużyć model analizy lingwistycznej Józefa Darskiego [1987; 2004; 2010; 2012], ponieważ umożliwia on szczegółowy i jednolity opis wszystkich słowoform odmiennych ze względu na wyrażane przez nie kategorie gramatyczne względnie funkcje. Autor „Lingwistycznego modelu analizy” („Linguistisches Analysemodell") zaznaczał wielokrotnie w swych publikacjach, iż model analizy jego autorstwa nadaje się wyłącznie do badań synchronicznych nad językiem. W swoich rozważaniach Darski dąży do precyzji, która z jednej strony umożliwia mu prezentację swojego modelu na przykładzie wybranych języków europejskich, tj. języka niemieckiego, angielskiego, francuskiego i polskiego, z drugiej jednak pozwala osiągnąć taki stopień abstrakcji, który gwarantuje udane zastosowanie wspomnianego modelu do badań nad innymi językami. Michail L. Kotin [2008; 2012] wykazał natomiast, iż model Darskiego może z powodzeniem znaleźć zastosowanie w badaniach diachronicznych.

W tym miejscu konieczna jest prezentacja fundamentalnych postulatów Darskiego. Punkt wyjścia analizy stanowią słowoformy danego wypowiedzenia, przy czym dana słowoforma składa się z tematu (referenzieller Stamm) i wykładników syntaktycznych (syntaktische Exponenten) [por. Darski 2010: 129n., 139-146]. Temat, który równocześnie jest nośnikiem znaczenia, stanowią w przypadku czasownika środki językowe wspólne wszystkim słowoformom tego samego leksemu w danym paradygmacie koniugacyjnym. Natomiast środki językowe, realizowane w słowoformach leksemów liczby pojedynczej lub mnogiej i niewchodzące w skład tematów fleksyjnych, to wykładniki syntaktyczne. Tę tezę zilustruję na przykładzie czasownika mocnego (wzg. nieregularnego) nehmen ('brać, wziąć') w czasie teraźniejszym trybu przypuszczającego strony czynnej ${ }^{1}$.

\footnotetext{
${ }^{1}$ Analizy przeprowadzane są każdorazowo na płaszczyźnie fonologicznej, bowiem pozwala to osiągnąć taki stopień perfekcji lingwistycznej, który jest niemożliwy w przypadku analiz (orto)graficznych. Równocześnie można pozyskać nowe ustalenia, które być może zrewidują tradycyjne lub też pozwolą na ich nową ocenę.
} 
Tabela 1. Koniugacja czasownika nehmen ('wziąć, brać') w czasie teraźniejszym trybu przypuszczającego strony czynnej [źródło: oprac. własne]

1. poj. $1 . \mathrm{mn}$.
1. /n'e:mə/
1. /n'e:mən/
2. /n'e:məst/
2. /n'e:mot/
3. /n'e:mə/
3. /n'e:mən/

Paradygmat koniugacyjny czasownika nehmen wykazuje /n'e:mə/ jako temat oraz następujące, zestawione w tabeli 2, wykładniki syntaktyczne czasu teraźniejszego trybu przypuszczającego strony czynnej, przy czym znak $ø$ symbolizuje tzw. wykładnik zerowy.

Tabela 2. Wykładniki syntaktyczne czasu teraźniejszego trybu przypuszczającego strony czynnej dla czasownika nehmen ('wziąć, brać') [źródło: oprac. własne]
1. poj.
1. $\mathrm{mn}$.

\begin{tabular}{|l|l|}
\hline $1 . \varnothing$ & $1 . / \mathrm{n} /$ \\
\hline $2 . / \mathrm{st} /$ & $2 . / \mathrm{t} /$ \\
\hline $3 . \varnothing$ & $3 . / \mathrm{n} /$ \\
\hline
\end{tabular}

Jednakże istnieją o wiele bardziej skomplikowane formy tegoż czasownika czy też o wiele bardziej skomplikowane czasowniki niż czasownik nehmen, które np. ze względu na zmianę samogłoski rdzennej czy ubezdźwięcznienie w wygłosie wykazują wewnątrztematyczne zmiany samo- i spółgłosek. Regularną wymianę samogłosek i/lub spółgłosek zaznacza Darski za pomocą wielkich liter. Postulaty te zobrazuję na przykładzie mocnego czasownika nehmen (por. tabela 3) i słabego (wzg. regularnego) czasownika salben ('namaścić, namaszczać') (por. tabela 4) w czasie teraźniejszym trybu oznajmującego strony czynnej. 


\section{MARTA WOŹNICKA}

Tabela 3. Koniugacja czasownika nehmen ('wziąć, brać') w czasie teraźniejszym trybu oznajmującego strony czynnej [źródło: oprac. własne]

$$
\text { 1. poj. } \quad \text { 1. mn. }
$$
1. /n'e:mə/
1. /n'e:mən/
2. /nimst/
2. /ne:mt/
3. /nimt/
3. /n'e:mən/

Temat mocnego czasownika brzmi /nIm/, przy czym wielka litera /I/ sugeruje zmianę /e:/ do /I/. /e:/ występuje w 1. os. 1. poj. oraz w całym paradygmacie liczby mnogiej, a /I/ pojawia się w 2. i 3. os. 1. poj. Regularna wymiana samogłoski oraz pozostałe, dołączone do tematu środki językowe $(/ \mathrm{\partial} /, / \mathrm{st} /, / \mathrm{\jmath n} /, / \mathrm{t} /)$ traktujemy jako wykładniki syntaktyczne.

Tabela 4. Koniugacja czasownika salben ('namaścić, namaszczać') w czasie teraźniejszym trybu oznajmującego strony czynnej [źródło: oprac. własne]

$$
\text { 1. poj. } \quad \text { 1. mn. }
$$

\begin{tabular}{|l|l|}
\hline 1. /z’albə/ & 1. /z'albmi/ \\
\hline 2. /zalpst/ & 2. /zalpt/ \\
\hline 3. /zalpt/ & 3. /z'albm// \\
\hline
\end{tabular}

Temat słabego czasownika brzmi natomiast/zalP/, przy czym /P/ realizowane jest w 1. os. 1. poj. oraz w 1. i 3. os. 1. mn. jako dźwięczna dwuwargowa zwartowybuchowa głoska /b/, tj. w słowoformach, w których po /P/ występują samogłoski (/ə/) lub spółgłoski zwarto-otwarte (/m/). W pozostałych przypadkach, tj. gdy po /P/ występuje (występują) inna głoska (inne głoski) niż samogłoska czy spółgłoska zwarto-otwarta (/st/,/t/), /P/ wymawiane jest jako bezdźwięczna bilabialna zwarto-wybuchowa głoska /p/. Obie możliwe realizacje /P/ oraz pozostałe środki językowe dołączone do tematu to wykładniki syntaktyczne, wskazujące na funkcje gramatyczne danej słowoformy, np. realizacja /P/ jako /b/ oraz neutralna samogłoska /ə/ to wykładniki syntaktyczne dla 1 os. 1. poj.

Opierając się na ustaleniach Kotina [por. 2008: 171], środki językowe tematów można podzielić na dwie grupy: 1) stałe (oznaczone małymi literami) oraz 2) zmienne (opatrzone wielkimi literami), przy czym ostatnie są dualistycznej natury, tj. funkcjonują jako elementy tematu i równocześnie jako wykładniki 
syntaktyczne. Należy również zaznaczyć, że istnieją takie czasowniki, jak np. czasownik sein ('być'), których w czasie teraźniejszym trybu oznajmującego nie można podzielić na temat i wykładnik syntaktyczny, bowiem obie funkcje uległy kontaminacji [por. Kotin 2008: 189] (por. tabela 5).

Tabela 5. Koniugacja czasownika sein ('być') w czasie teraźniejszym trybu oznajmującego strony czynnej [źródło: oprac. własne]

$$
\text { 1. poj. } \quad 1 . \mathrm{mn} \text {. }
$$

\begin{tabular}{|l|l|}
\hline 1. /bin/ & 1. zint/ \\
\hline 2. /bist/ & 2. zact/ \\
\hline 3. / PIst/ & 3. /zint/ \\
\hline
\end{tabular}

W takich przypadkach Darski [por. 2010: 128] proponuje potraktować całą słowoformę jednocześnie jako temat i wykładnik syntaktyczny.

Model budowy słowoform według Darskiego jest zorganizowany hierarchicznie. Ponieważ ten krótki referat traktuje o fleksji czasownika, hierarchia zostanie zaprezentowana na przykładzie paradygmatu koniugacyjnego czasowników nehmen oraz salben w stronie czynnej. Najniższy stopień abstrakcji stanowi temat czasownika w l. poj. lub mn. tego samego czasu i trybu. Tematy czasowników nehmen oraz salben w czasie teraźniejszym i w trybie oznajmującym brzmią /nIm/ i /zalP/, przy czym /I/ i /P/ sugerują omówione wcześniej wymiany głosek, a tematy składają się zarówno z elementów stałych $(/ \mathrm{n} /$ oraz /m/ w przypadku nehmen, /zal/ w przypadku salben), jak i zmiennych (/I/ oraz $/ \mathrm{P} /$ ). Temat czasownika mocnego w liczbie mnogiej składa się jedynie ze stałych środków językowych (/ne:m/), natomiast czasownik salben wykazuje w liczbie mnogiej identyczny temat jak w liczbie pojedynczej (/zalP/). Abstrahując od opozycji liczba pojedyncza : liczba mnoga, uzyskujemy tzw. neutralny pod względem liczby temat czasu teraźniejszego trybu oznajmującego (/nIm/, /zalP/), przy czym wielka litera odnosi się do regularnej wymiany samoi spółgłosek zarówno w 1. poj., jak i, jeśli ma to miejsce, 1. mn. Ponieważ jednak wymiana samogłoski w przypadku czasownika mocnego występuje tylko w 1. poj., należy ją potraktować jako wskaźnik liczby pojedynczej (Singularmarker) [por. Darski 2010: 133]. W ten sam sposób pozyskujemy neutralne pod względem liczby: 1) tematy czasu teraźniejszego trybu rozkazującego i przypuszczającego, 2) tematy czasu przeszłego narracyjnego (prostego) trybu 


\section{MARTA WOŹNICKA}

oznajmującego i przypuszczającego. Najwyższy stopień abstrakcji osiągamy poprzez pominięcie opozycji trybów (tryb oznajmujący:tryb rozkazujący : tryb przypuszczający, przy czym tryb rozkazujący ograniczony jest do czasu teraźniejszego) i dalej czasów (czas teraźniejszy : czas przeszły narracyjny (prosty)). Neutralne pod względem liczby, trybu i czasu tematy przykładowych czasowników brzmią /nIm/ oraz /zalP/ [por. Darski 2010: 146nn.]. Schematy 1 i 2 przedstawiają kolejne kroki abstrakcji, z tym że od najwyższego do najniższego poziomu.

/nIm/, w zależności od czasu, ma dwa warianty: /nIm/ dla czasu teraźniejszego i /nAm/ dla czasu przeszłego narracyjnego. Realizacja /I/ jako /I/ musi zatem zostać potraktowana jako znacznik czasu teraźniejszego, a realizacja /I/ jako /A/ jako znacznik czasu przeszłego narracyjnego. W czasie teraźniejszym występują, w zależności od trybu, dwa tematy: 1) /nIm/ dla trybu oznajmującego i rozkazującego oraz 2) /ne:mə/ dla trybu przypuszczającego. Temat trybu przypuszczającego różni się od tematu trybu oznajmującego i rozkazującego tzw. samogłoską neutralną schwa (shwa) /ə/, którą należy potraktować jako znacznik trybu przypuszczającego [por. Darski 2010: 146nn.]. W związku z tym realizację /I/ jako /I/ należy uznać za znacznik trybu oznajmującego względnie rozkazującego. W czasie przeszłym pojawiają się z kolei, w zależności od trybu, dwa tematy: 1) /na:m/ (tryb oznajmujący) oraz 2) /ne:mə/ (tryb przypuszczający). Znacznikiem trybu oznajmującego jest /a:/, tymczasem na tryb przypuszczający wskazują /ع:/ i samogłoska neutralna /ə/ (por. schemat 1).

Schemat 1. Tematy referencyjne czasownika nehmen ('wziąć, brać') [źródło: oprac. własne] /nIm/

\begin{tabular}{cccc}
\multicolumn{2}{c}{$/ \mathrm{nIm} /$} & \multicolumn{2}{c}{$/ \mathrm{nAm} /$} \\
(czas teraźniejszy) & $/ \mathrm{ne:mə/}$ & (czas przeszły narracyjny) \\
/nIm/ & (tryb przy- & (tryb oznajmujący) & (tryb przy- \\
(tryb oznajmujący & puszczający) & & puszczający)
\end{tabular}

/zalP/ dysponuje w zależności od czasu dwoma wariantami: /zalP/ (czas teraźniejszy) oraz /zalpt/ (czas przeszły narracyjny). Pomiędzy tematem czasu teraźniejszego i przeszłego można zauważyć istotne różnice, które należy potraktować jako znaczniki danego czasu: /P/ jako /b/ to znacznik czasu teraźniejszego, a /t/ to znacznik czasu przeszłego. W czasie teraźniejszym 
występują osobno dla trybu oznajmującego i rozkazującego oraz trybu przypuszczającego dwa tematy: /zalP/ (tryb oznajmujący i rozkazujący) oraz /zalb/ (tryb przypuszczający). Również i tu, podobnie jak w przypadku znaczników liczby czy czasu, można potraktować realizację /P/ jako /p/ jako wskaźnik trybu oznajmującego względnie rozkazującego (por. schemat 2).

Schemat 2. Tematy referencyjne czasownika salben ('namaścić', 'namaszczać') [źródło: oprac. własne]

/zalP/

$\begin{array}{cc}\text { /zalP/ } & \text { /zalpt/ } \\ \text { (czas teraźniejszy) } & \begin{array}{c}\text { (czas przeszły narracyjny trybu } \\ \text { oznajmującego i przypuszczającego) }\end{array} \\ \text { /zalP/ } & \text { /zalb/ } \\ \text { tryb oznajmujący } & \text { (tryb przy- } \\ \text { i rozkazujący) } & \text { puszczający) }\end{array}$

Moim zamiarem jest przedstawienie metody opierającej się na modelu Darskiego, dzięki której uzyskamy wgląd w rozwój fleksji czasownika niemieckiego, od języka gockiego, który najlepiej dokumentuje stan języków germańskich, po współczesną niemczyznę. Ponieważ w ramach referatu nie ma możliwości przedstawienia pełnej analizy historycznego materiału językowego, do tego celu zostały wybrane mikroparadygmaty czasowników nehmen oraz salben. Na przykładzie tych czasowników chcę pokazać:

1) jak zmieniały się stałe i zmienne elementy tematu fleksyjnego;

2) jak rozwinęły się wykładniki syntaktyczne dla czasownika mocnego.

W pierwszej kolejności ustalam synchronicznie neutralne pod względem liczby, trybu i czasu tematy przykładowych czasowników, które następnie poddaję analizom diachronicznym.

Neutralny temat fleksyjny przykładowego czasownika mocnego jest identyczny dla wszystkich etapów historycznych: /nIm/, tj. tematy wykazują każdorazowo jeden zmienny element samogłoskowy /I/. Jednak w zależności od etapu /I/ ma różne realizacje. 


\section{MARTA WOŹNICKA}

W gockim /I/ realizowane jest na trzy różne sposoby:

1) /i/ w czasie teraźniejszym wszystkich trybów;

2) /a/ w 1. poj. czasu przeszłego trybu oznajmującego;

3) /e:/ w 1. podw. i mn. czasu przeszłego trybu oznajmującego oraz w całym paradygmacie czasu przeszłego trybu przypuszczającego (por. tabela 6).

Tabela 6. Fonologiczne wzory koniugacyjne dla gockiego czasownika niman ('wziąć, brać') [źródło: oprac. własne]

\section{GOCKI /nIm/}

\begin{tabular}{|c|c|c|c|c|c|}
\hline & TO & TP & TR & PO & $\mathbf{P P}^{2}$ \\
\hline \multirow{2}{*}{$\begin{array}{l}\text { Temat } \\
\text { flek- } \\
\text { syjny }\end{array}$} & $/ \mathrm{nim} /$ & /nimAU/ & /nim/ & $/ \mathrm{nAm} /$ & /ne:m/ \\
\hline & $\begin{array}{l}\text { 1.poj. } \\
\text { 1./a/ } \\
\text { 2./Is/ } \\
\text { 3./I } \theta /\end{array}$ & $\begin{array}{l}\text { l.poj. } \\
\text { 1./AU/ jako /aud/ } \\
\text { 2./AU/ jako /aĩ/+/s/ } \\
\text { 3./AU/ jako /ai / }\end{array}$ & $\begin{array}{l}\text { 1.poj. } \\
\text { 1.ø } \\
\text { 2./aðau్/ }\end{array}$ & $\begin{array}{l}\text { 1.poj. } \\
\text { 1./A/ jako /a/ } \\
\text { 2./A/ jako /a/+/t/ } \\
\text { 3./A/ jako /a/ }\end{array}$ & $\begin{array}{l}\text { 1.poj. } \\
\text { 1./jaud/ } \\
\text { 2./i:s/ } \\
\text { 3./i/ }\end{array}$ \\
\hline \multirow[t]{2}{*}{$\begin{array}{l}\text { Wzór } \\
\text { koniu- } \\
\text { gacyjny }\end{array}$} & $\begin{array}{l}\text { 1.podw. } \\
\text { 1./o:s/ } \\
\text { 2./ats/ }\end{array}$ & $\begin{array}{l}\text { 1.podw. } \\
\text { 1./AU/ jako /ai / +/wal } \\
\text { 2./AU/ jako /ai / /tts/ }\end{array}$ & $\begin{array}{l}\text { 1.podw. } \\
\text { 2./ats/ }\end{array}$ & $\begin{array}{l}\text { 1.podw. } \\
\text { 1./A/ jako /e:/+/u/ } \\
\text { 2./A/ jako /e:/+/uts/ }\end{array}$ & $\begin{array}{l}\text { 1.podw. } \\
\text { 1./i:wa/ } \\
\text { 2. /i:ts/ }\end{array}$ \\
\hline & $\begin{array}{l}\text { 1.mn. } \\
\text { 1./am/ } \\
\text { 2./I } \theta / \\
\text { 3./and/ }\end{array}$ & $\begin{array}{l}\text { l.mn. } \\
\text { 1./AU/ jako } / \mathrm{ai} /+/ \mathrm{ma} / \\
\text { 2./AU/ jako } / \mathrm{ai} /+/ \theta / \\
\text { 3./AU/ jako } / \mathrm{ai} /+/ \mathrm{na}^{\beta} /\end{array}$ & $\begin{array}{l}\text { l.mn. } \\
\text { 1./am/ } \\
\text { 2./I } \theta / \\
\text { 3./andau/ }\end{array}$ & $\begin{array}{l}\text { 1.mn. } \\
\text { 1./A/ jako /e:/+/um/ } \\
\text { 2./A/ jako /e:/+/u } \theta / \\
\text { 3./A/ jako /e:/+/un/ }\end{array}$ & $\begin{array}{l}\text { l.mn. } \\
\text { 1. /i:ma/ } \\
\text { 2. /i: } \theta / \\
\text { 3. /i:na/ }\end{array}$ \\
\hline
\end{tabular}

W porównaniu do gockiego /I/ realizowane jest w staro-wysoko-niemieckim (z powodu różnic w paradygmacie czasu teraźniejszego) na cztery różne sposoby (por. tabela 7).

\footnotetext{
2 Skróty oznaczają każdorazowo: 'TO' - czas teraźniejszy trybu oznajmującego, 'TP' czas teraźniejszy trybu przypuszczającego, 'TR' - czas teraźniejszy trybu rozkazującego; 'PO' - czas przeszły trybu oznajmującego; 'PP' - czas przeszły trybu przypuszczającego. ${ }^{3}$ Wartość fonologiczna grafemów podwójnych <ai> oraz <au> po dziś dzień wzbudza kontrowersje. Już Hans von der Gabelentz i Julius Loebe (1846: II, 2, § 28) zakładali,

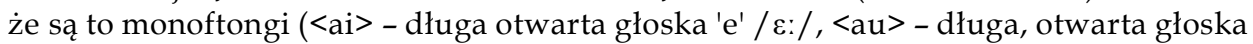
'o' / o:/). W tym artykule przyjmuje sie jednakże status dyftongalny obu grafemów (por. m.in. Kotin 2012: 46).
} 
Tabela 7. Fonologiczne wzory koniugacyjne dla czasownika staro-wysoko-niemieckiego nëman ('wziąć, brać') [źródło: oprac. własne].

\section{STARO-WYSOKO-NIEMIECKI /nIm/}

\begin{tabular}{|c|c|c|c|c|c|}
\hline & TO & TP & TR & PO & PP \\
\hline $\begin{array}{c}\text { Temat } \\
\text { fleksyiny }\end{array}$ & /nIm/ & /nEm\&/ & $/ \mathrm{nIm} /$ & $/ \mathrm{nAm} /$ & /na:mI/ \\
\hline Wzór & $\begin{array}{l}\text { 1. poj. } \\
\text { 1. /I/ jako /i/ } \\
+/ \mathrm{u} / \\
\text { 2. /I/ jako /i/ } \\
\text { +/is/ } \\
\text { 3. /I/ jako /i/ } \\
+/ \text { it/ }\end{array}$ & $\begin{array}{l}\text { 1. poj. } \\
\text { 1. /E/ jako /e/ } \\
\text { 2. /E/ jako /e:/ } \\
\text { +/s/ } \\
\text { 3. /E/ jako /e/ }\end{array}$ & $\begin{array}{l}\text { 1. poj. } \\
\text { 2. /I/ jako /i/ }\end{array}$ & $\begin{array}{l}\text { 1. poj. } \\
\text { 1. /A/ jako /a/ } \\
\text { 2. /A/ jako /a:/ } \\
\text { +/i/ } \\
\text { 3. /A/ jako /a/ }\end{array}$ & $\begin{array}{l}\text { 1. poj. } \\
\text { 1. /I/ jako /i/ } \\
\text { 2. /I/ jako /i:/ } \\
\text { +/s/ } \\
\text { 3. /I/ jako /i/ }\end{array}$ \\
\hline $\begin{array}{l}\text { koniu- } \\
\text { gacyjny }\end{array}$ & 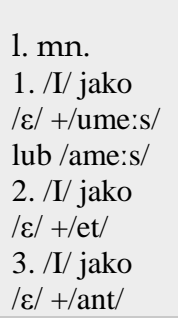 & $\begin{array}{l}\text { 1. mn. } \\
\text { 1. /E/ jako /e:/ } \\
+/ \mathrm{m} / \\
2 . / \mathrm{E} / \text { jako /e:/ } \\
+/ \mathrm{t} / \\
\text { 3. /E/ jako /e:/ } \\
+/ \mathrm{n} /\end{array}$ & $\begin{array}{l}\text { 1. mn. } \\
\text { 2. /I/ jako / } / \text { / } \\
+ \text { let/ }\end{array}$ & $\begin{array}{l}\text { 1. mn. } \\
\text { 1. /A/ jako /a:/ } \\
\text { +/um/ } \\
\text { 2. /A/ jako /a:/ } \\
\text { +/ut/ } \\
\text { 3. /A/ jako /a:/ } \\
\text { +/un/ }\end{array}$ & $\begin{array}{l}\text { 1. mn. } \\
\text { 1. /I/ jako /i:/ } \\
+/ \mathrm{m} / \\
\text { 2. /I/ jako /i:/ } \\
+/ \mathrm{t} / \\
\text { 3. /I/ jako /i:/ } \\
+/ \mathrm{n} /\end{array}$ \\
\hline
\end{tabular}

W czasie przeszłym trybu oznajmującego fleksja wewnętrzna została wprawdzie ujednolicona, mimo to pojawiają się w tym paradygmacie dwie różne realizacje /I/, ponieważ samogłoska /a/ w 1. i 3. os. 1. poj. jest krótka. /I/ realizowane jest zatem w staro-wysoko-niemieckim jako:

1) /i/ w 1. poj. czasu teraźniejszego trybu oznajmującego i rozkazującego, co należy potraktować jako proces asymilacyjny, tj. tzw. podwyższenie artykulacji samogłoski / $\varepsilon /$ do /i/ przed /u/ lub /i/ kolejnej sylaby [por. m.in. Meineke/Schwerdt 2001: 186];

2) $/ \varepsilon / \mathrm{w}$ l. mn. czasu teraźniejszego trybu oznajmującego, w całym paradygmacie czasu teraźniejszego trybu przypuszczającego oraz w 1 . mn. czasu teraźniejszego trybu rozkazującego;

3) /a/ w 1. i 3. os. 1. poj. czasu przeszłego trybu oznajmującego;

4) /a:/ w 2. os. 1. poj. czasu przeszłego trybu oznajmującego, przy czym pochodzenie tej samogłoski jest niepewne [por. Meineke/Schwerdt 2001: 277], w 1. mn. czasu przeszłego trybu oznajmującego oraz w całym paradygmacie czasu przeszłego trybu przypuszczającego. 


\section{MARTA WOŹNICKA}

Średnio-wysoko-niemieckie /I/ ma natomiast aż pięć możliwych wariantów realizacji (por. tabela 8 ).

Tabela 8. Fonologiczne wzory koniugacyjne dla czasownika średnio-wysoko-niemieckiego nëmen ('wziąć, brać') [źródło: oprac. własne]

\section{ŚREDNIO-WYSOKO-NIEMIECKI /nIm/}

\begin{tabular}{|c|c|c|c|c|c|}
\hline & TO & TP & TR & PO & PP \\
\hline $\begin{array}{c}\text { Temat } \\
\text { fleksyjny }\end{array}$ & /nImə/ & /nemə/ & $/ \mathrm{nIm} /$ & /nAm/ & /næ:mə/ \\
\hline Wzór & $\begin{array}{l}\text { 1. poj. } \\
\text { 1. /I/ jako /i/ } \\
\text { 2. /// jako /i// } \\
+/ \text { st/ } \\
\text { 3. /I/ jako /i/ } \\
+/ \mathrm{t} /\end{array}$ & $\begin{array}{l}\text { 1. poj. } \\
\text { 1. } \\
\text { 2. /st/ } \\
\text { 3. }\end{array}$ & $\begin{array}{l}\text { 1. poj. } \\
\text { 2. /I/ jako /i/ }\end{array}$ & $\begin{array}{l}\text { 1. poj. } \\
\text { 1. /A/ jako /a/ } \\
\text { 2. /A/ jako /æ:/ } \\
\text { +/a/ } \\
\text { 3. /A/ jako /a/ }\end{array}$ & $\begin{array}{l}\text { 1. poj. } \\
\text { 1. } \\
\text { 2. /st/ } \\
\text { 3. }\end{array}$ \\
\hline $\begin{array}{l}\text { koniu- } \\
\text { gacyjny }\end{array}$ & $\begin{array}{l}\text { 1. mn. } \\
1 . / \mathrm{I} / \text { jako } \\
/ \varepsilon /+/ \mathrm{n} / \\
2 . / \mathrm{I} / \text { jako } \\
/ \varepsilon /+/ \mathrm{t} / \\
3 . / \mathrm{I} / \text { jako } \\
/ \varepsilon /+/ \mathrm{nt} /\end{array}$ & $\begin{array}{l}\text { 1. } \mathrm{mn} . \\
1 . / \mathrm{n} / \\
2 . / \mathrm{t} / \\
3 . / \mathrm{n} /\end{array}$ & $\begin{array}{l}\text { 1. mn. } \\
\text { 2. /I/ jako / } / \text { / } \\
+/ \text { tot }\end{array}$ & $\begin{array}{l}\text { 1. mn. } \\
\text { 1. /A/ jako /a:/ } \\
\text { +/ən/ } \\
\text { 2. /A/ jako /a:/ } \\
\text { +/at/ } \\
\text { 3. /A/ jako /a:/ } \\
\text { +/ən/ }\end{array}$ & $\begin{array}{l}1 . \mathrm{mn} . \\
1 . / \mathrm{n} / \\
2 . / \mathrm{t} / \\
3 . / \mathrm{n} /\end{array}$ \\
\hline
\end{tabular}

Od staro-wysoko-niemieckiego /I/ różni się średnio-wysoko-niemieckie /I/ realizacją jako /æ:/ w 2. os. 1. poj. czasu przeszłego trybu oznajmującego oraz w całym paradygmacie czasu przeszłego trybu przypuszczającego. Ten wariant jest wynikiem procesu asymilacyjnego, tj. tzw. przegłosu wtórnego [por. m.in. Penzl 1970; Twadell 1970; Moser/Welmann/Wolf 1981: 53-57; Szulc 2002: 126; 129n.; Hennings 2003: 58-61; Schmidt et al. 2004: 254; Paul 2007: 71nn.].

Ostatecznie nowo-wysoko-niemieckie /I/ ma, podobnie jak jego staro-wysokoniemiecki odpowiednik, cztery, mimo że odmienne, warianty realizacji:

1) /I/ w 2. i 3. os. 1. poj. czasu teraźniejszego trybu oznajmującego oraz w l. poj. czasu teraźniejszego trybu rozkazującego;

2) le:/ w 1. os. 1. poj. czasu teraźniejszego trybu oznajmującego; w całym paradygmacie 1. mn. czasu teraźniejszego trybu oznajmującego, przy czym przy przejściu ze średnio- do nowo-wysoko-niemieckiego doszło do wydłużenia samogłoski akcentowanej (średnio-wysoko-niemieckie 
/\&/i nowo-wysoko-niemieckie / $:$ :/) [por. Szulc 2002: 150]; w całym paradygmacie czasu teraźniejszego trybu przypuszczającego oraz w $1 . \mathrm{mn}$. czasu teraźniejszego trybu rozkazującego;

3) /a:/ w czasie przeszłym narracyjnym trybu oznajmującego, przy czym w obrębie tego paradygmatu nastąpiło ujednolicenie poprzez analogię (por. koniugację średnio-wysoko-niemieckiego czasownika nëmen w czasie przeszłym trybu oznajmującego [por. Szulc 2002: 151; Schmidt et al. 2004: 312];

4) $/ \varepsilon: / \mathrm{w}$ paradygmacie czasu przeszłego trybu przypuszczającego (por. tabela 9).

Tabela 9. Fonologiczne wzory koniugacyjne dla czasownika nowo-wysoko-niemieckiego nehmen ('wziąć, brać') [źródło: oprac. własne]

\section{NOWO-WYSOKO-NIEMIECKI /nIm/}

TO

TP

TR

PO

PP

\begin{tabular}{|c|c|c|c|c|c|}
\hline Temat & $/ \mathrm{nIm} /$ & /ne:mə/ & $/ \mathrm{nIm} /$ & /na:m/ & /nc:mə/ \\
\hline $\begin{array}{l}\text { Wzór } \\
\text { koniu- } \\
\text { gacyjny }\end{array}$ & $\begin{array}{l}\text { 1. poj. } \\
\text { 1. /I/ jako /e:/ } \\
+/ \mathrm{\partial} / \\
\text { 2. /I/ jako /I/ } \\
\text { +/st/ } \\
\text { 3. /I/ jako /I/ } \\
\text { +/t/ } \\
\text { 1. mn. } \\
\text { 1. /I/ jako /e:/ } \\
\text { +/en/ } \\
\text { 2. /I/ jako /e:/ } \\
\text { +/t/ } \\
\text { 3. /I/ jako /e:/ } \\
\text { +/en/ }\end{array}$ & $\begin{array}{l}\text { 1. } \mathrm{mn} . \\
1 . / \mathrm{n} / \\
2 . / \mathrm{t} / \\
3 . / \mathrm{n} /\end{array}$ & $\begin{array}{l}\text { 1. mn. } \\
\text { 2. /I/ jako /e/ } \\
+/ \text { t/ } \\
\text { 3. /I/ jako /e:/ } \\
\text { +/ən/ }\end{array}$ & $\begin{array}{l}\text { 1. } \mathrm{mn} . \\
\text { 1. /en/ } \\
\text { 2. /t/ } \\
\text { 3. /en/ }\end{array}$ & $\begin{array}{l}\text { 1. mn. } \\
1 . / \mathrm{n} / \\
2 . / \mathrm{t} / \\
3 . / \mathrm{n} /\end{array}$ \\
\hline
\end{tabular}




\section{MARTA WOŹNICKA}

Słaby czasownik ma natomiast cztery różne, zależne od etapu historycznego rozwoju, neutralne tematy fleksyjne. Temat gockiego czasownika składa się wyłącznie ze stałych środków językowych: /salbo:/ (por. tabela 10).

Tabela 10. Fonologiczne wzory koniugacyjne dla gockiego czasownika salbôn ('namaścić, namaszczać') [źródło: oprac. własne]

\section{GOCKI /salbo:/}

\begin{tabular}{|c|c|c|c|c|c|}
\hline & TO & TP & TR & PO & PP \\
\hline \multirow{2}{*}{$\begin{array}{c}\text { Temat } \\
\text { fleksyjny }\end{array}$} & /salbo:/ & /salbo:/ & /salbo:/ & /salbo:ðA/ & /salbo:ðe:ð/ \\
\hline & $\begin{array}{l}\text { 1. poj. } \\
\text { 1. } \varnothing \\
\text { 2. } / \mathrm{s} / \\
\text { 3. } / \theta /\end{array}$ & $\begin{array}{l}\text { 1. poj. } \\
\text { 1. } \\
\text { 2. /s/ } \\
\text { 3. }\end{array}$ & $\begin{array}{l}\text { 1. poj. } \\
\text { 1. ø } \\
\text { 2. /ðau// }\end{array}$ & $\begin{array}{l}\text { 1. poj. } \\
\text { 1. /A/ jako /a/ } \\
\text { 2. /A/ jako /a/+/s/ } \\
\text { 3. /A/ jako /a/ }\end{array}$ & $\begin{array}{l}\text { 1. poj. } \\
\text { 1. /jaud/ } \\
\text { 2. /i:s/ } \\
\text { 3. /i/ }\end{array}$ \\
\hline \multirow[t]{2}{*}{$\begin{array}{l}\text { Wzór } \\
\text { koniu- } \\
\text { gacyjny }\end{array}$} & $\begin{array}{l}\text { 1. podw. } \\
\text { 1./s/ } \\
2 . / \mathrm{ts} /\end{array}$ & $\begin{array}{l}\text { 1. podw. } \\
\text { 1. /wa/ } \\
2 . / \mathrm{ts} /\end{array}$ & $\begin{array}{l}\text { 1. podw. } \\
\text { 2. /ts/ }\end{array}$ & $\begin{array}{l}\text { 1. podw. } \\
\text { 1. /A/ jako /e:/+/ðu/ } \\
\text { 2. /A/ jako /e:/+/ðuts/ }\end{array}$ & \\
\hline & $\begin{array}{l}\text { 1. } \mathrm{mn} \text {. } \\
1 . / \mathrm{m} / \\
2 . / \theta / \\
\text { 3. } / \mathrm{nd} /\end{array}$ & $\begin{array}{l}\text { 1. } \mathrm{mn} . \\
1 . / \mathrm{ma} / \\
\text { 2. } / \theta / \\
\text { 3. } / \mathrm{na} /\end{array}$ & $\begin{array}{l}\text { 1. mn. } \\
1 . / \mathrm{m} / \\
\text { 2. } / \theta / \\
\text { 3. } / \text { ndau } /\end{array}$ & $\begin{array}{l}\text { 1. mn. } \\
\text { 1. /A/ jako /e:/+/ðum/ } \\
\text { 2. /A/ jako /e:/+/ðu } \theta / \\
\text { 3. /A/ jako /e:/+/ðun/ }\end{array}$ & $\begin{array}{l}\text { 1. mn. } \\
\text { 1. /i:ma/ } \\
\text { 2. /i: } \theta / \\
\text { 3. /i:na/ }\end{array}$ \\
\hline
\end{tabular}

W staro-wysoko-niemieckim temat wykazuje jeden zmienny samogłoskowy element /O/ (/salbO/), który ma dwie możliwe realizacje, tj.:

1) /o:/ w czasie teraźniejszym trybu oznajmującego, w 2. os. 1. poj. oraz w 1. mn. czasu teraźniejszego trybu przypuszczającego, w 1 . mn. czasu teraźniejszego trybu rozkazującego, w czasie przeszłym narracyjnym trybu oznajmującego i przypuszczającego;

2) /o/ w 1. i 3. os. 1. poj. czasu teraźniejszego trybu przypuszczającego, w 1. poj. czasu teraźniejszego trybu rozkazującego, co tłumaczone jest regularną redukcją $\mathrm{w}$ niechronionej pozycji, tj. w tzw. wygłosie absolutnym (por. tabela 11). 
Tabela 11. Fonologiczne wzory koniugacyjne dla czasownika staro-wysoko-niemieckiego salbôn ('namaścić, namaszczać') [źródło: oprac. własne]

\section{STARO-WYSOKO-NIEMIECKI /salbO/}

\begin{tabular}{|c|c|c|c|c|c|}
\hline & TO & TP & TR & PO & PP \\
\hline $\begin{array}{l}\text { Temat } \\
\text { fleksyiny }\end{array}$ & /salbo:/ & /salbO/ & /salbO/ & /salbo:t/ & /salbo:tI/ \\
\hline Wzór & $\begin{array}{l}\text { 1. poj. } \\
1 .+/ \mathrm{m} / \\
2 .+/ \mathrm{s} / \\
3 .+/ \mathrm{t} /\end{array}$ & $\begin{array}{l}\text { 1. poj. } \\
\text { 1. /O/ jako /o/ } \\
\text { 2. /O/ jako /o:/ } \\
+/ \mathrm{s} / \\
\text { 3. /O/ jako /o/ }\end{array}$ & $\begin{array}{l}\text { 1. poj. } \\
\text { 2. /O/ jako /o/ }\end{array}$ & $\begin{array}{l}\text { 1. poj. } \\
\text { 1. +/a/ } \\
\text { 2. + /o:s/ } \\
\text { 3. +/a/ }\end{array}$ & $\begin{array}{l}\text { 1. poj. } \\
\text { 1. /I/ jako /i// } \\
\text { 2. /I/ jako /i:/ } \\
\text { +/s/ } \\
\text { 3. /I/ jako /i/ }\end{array}$ \\
\hline $\begin{array}{l}\text { koniu- } \\
\text { gacyjny }\end{array}$ & $\begin{array}{l}\text { 1. mn. } \\
\text { 1. + /me:s/ } \\
\text { 2. }+/ \mathrm{t} / \\
\text { 3. }+/ \mathrm{nt} /\end{array}$ & $\begin{array}{l}\text { 1. mn. } \\
\text { 1. /O/ jako /o:/ } \\
+/ \mathrm{m} / \\
2 . / \mathrm{O} / \text { jako /o:/ } \\
+/ \mathrm{t} / \\
\text { 3. /O/ jako /o:/ } \\
+/ \mathrm{n} /\end{array}$ & $\begin{array}{l}\text { 1. mn. } \\
\text { 2. /O/ jako /o:/ } \\
+/ \mathrm{t} /\end{array}$ & $\begin{array}{l}\text { 1. mn. } \\
\text { 1. +/um/ } \\
\text { 2. +/ut/ } \\
\text { 3. +/un/ }\end{array}$ & $\begin{array}{l}\text { 1. mn. } \\
\text { 1. /I/ jako /i:/ } \\
+/ \mathrm{m} / \\
\text { 2. /I/ jako /i:/ } \\
+/ \mathrm{t} / \\
\text { 3. /I/ jako /i:/ } \\
+/ \mathrm{n} /\end{array}$ \\
\hline
\end{tabular}

Średnio-wysoko-niemiecki temat słabego czasownika składa się ponownie ze stałych elementów (/salbə/) (por. tabela 12).

Tabela 12. Fonologiczne wzory koniugacyjne dla czasownika średnio-wysoko-niemieckiego salben ('namaścić, namaszczać') [źródło: oprac. własne]

\section{ŚREDNIO-WYSOKO-NIEMIECKI /salbə/}

\begin{tabular}{|c|c|c|c|c|c|}
\hline & TO & TP & TR & PO & PP \\
\hline $\begin{array}{c}\text { Temat } \\
\text { fleksyiny }\end{array}$ & /salbo:/ & /salbO/ & /salbO/ & /salbo:t/ & /salbo:tI/ \\
\hline $\begin{array}{l}\text { Wzór } \\
\text { koniu- } \\
\text { gacyjny }\end{array}$ & $\begin{array}{l}\text { 1. poj. } \\
\text { 1. } \\
2 .+/ \mathrm{st} / \\
\text { 3. +/t/ } \\
\text { 1. mn. } \\
1 .+/ \mathrm{n} / \\
2 .+/ \mathrm{t} / \\
3 .+\mathrm{nt} /\end{array}$ & $\begin{array}{l}\text { 1. poj. } \\
\text { 1. } \varnothing \\
\text { 2. }+/ \mathrm{st} / \\
\text { 3. } \varnothing \\
\\
1 . \mathrm{mn} . \\
1 .+/ \mathrm{n} / \\
2 .+/ \mathrm{t} / \\
\text { 3. }+/ \mathrm{n} /\end{array}$ & $\begin{array}{l}\text { 1. poj. } \\
\text { 2. } \varnothing\end{array}$ & $\begin{array}{l}\text { 1. poj. } \\
\text { 1. } \\
\text { 2. }+/ \mathrm{st} / \\
\text { 3. } \varnothing \\
\\
\text { 1. } \mathrm{mn} . \\
\text { 1. }+/ \mathrm{n} / \\
\text { 2. }+/ \mathrm{t} / \\
\text { 3. }+/ \mathrm{n} /\end{array}$ & $\begin{array}{l}\text { 1. poj. } \\
\text { 1. } \\
\text { 2. }+/ \mathrm{st} / \\
\text { 3. } \varnothing \\
\\
\text { 1. } \mathrm{mn} . \\
\text { 1. }+/ \mathrm{n} / \\
\text { 2. }+/ \mathrm{t} / \\
\text { 3. }+/ \mathrm{n} /\end{array}$ \\
\hline
\end{tabular}

W odróżnieniu do wcześniejszych etapów temat nowo-wysoko-niemieckiego czasownika salben wykazuje jeden zmienny spółgłoskowy element/P/, który realizowany jest jako dźwięczna bądź bezdźwięczna dwuwargowa głoska zwartowybuchowa (hasło: ubezdźwięcznienie w wygłosie): 


\section{MARTA WOŹNICKA}

1) /p/ realizowane jest w 2. i 3. os. 1. poj. oraz w 2. os. 1. mn. czasu teraźniejszego trybu oznajmującego, w 2. os. 1. poj. oraz w 1 . mn. czasu teraźniejszego trybu rozkazującego, w czasie przeszłym trybu oznajmującego i przypuszczającego;

2) /b/ pojawia się w 1. os. 1. poj. oraz w 1. i 3. os. 1. mn. czasu teraźniejszego trybu oznajmującego, w czasie teraźniejszym trybu przypuszczającego, w 2. os. 1. poj. i 3. os. 1. mn. czasu teraźniejszego trybu rozkazującego (por. tabela 13).

Tabela 13. Fonologiczne wzory koniugacyjne dla czasownika nowo-wysoko-niemieckiego salben ('namaścić, namaszczać') [źródło: oprac. własne]

\section{NOWO-WYSOKO-NIEMIECKI /zaIP/}

\begin{tabular}{|c|c|c|c|c|c|}
\hline & TO & TP & TR & PO & PP \\
\hline $\begin{array}{l}\text { Temat } \\
\text { fleksyjny }\end{array}$ & /zalP/ & /zalb/ & /zalP/ & /zalpt/ & /zalpt/ \\
\hline $\begin{array}{l}\text { Wzór } \\
\text { koniu- } \\
\text { gacyjny }\end{array}$ & $\begin{array}{l}\text { 1. poj. } \\
\text { 1. } / \mathrm{P} / \text { jako } / \mathrm{b} /+/ \mathrm{o} / \\
\text { 2. } / \mathrm{P} / \text { jako } / \mathrm{p} /+/ \mathrm{st} / \\
\text { 3. } / \mathrm{P} / \text { jako } / \mathrm{p} /+\mathrm{t} / \\
\text { 1. } \mathrm{mn} \text {. } \\
\text { 1. } / \mathrm{P} / \text { jako } / \mathrm{b} / \mathrm{t} / \mathrm{m} / \\
\text { 2. } / \mathrm{P} / \text { jako } / \mathrm{p} /+\mathrm{t} / \\
\text { 3. } / \mathrm{P} / \text { jako } / \mathrm{b} /+\mathrm{m} /\end{array}$ & $\begin{array}{l}\text { 1. poj. } \\
\text { 1. +/a/ } \\
2 .+/ \mathrm{st} / \\
3 .+/ \mathrm{a} / \\
\\
1 . \mathrm{mn} . \\
1 .+/ \mathrm{m} / \\
2 .+/ \mathrm{at} / \\
3 .+/ \mathrm{m} /\end{array}$ & $\begin{array}{l}\text { 1. poj. } \\
\text { 2. /P/ jako /p/ } \\
\text { wzg. /P/ jako /b/ } \\
+/ \mathrm{a} / \\
\text { 1. mn. } \\
\text { 2. } / \mathrm{P} / \text { jako } / \mathrm{p} /+/ \mathrm{t} / \\
\text { 3. } / \mathrm{P} / \text { jako } / \mathrm{b} /+\mathrm{m} /\end{array}$ & $\begin{array}{l}\text { 1. poj. } \\
1 .+/ \mathrm{a} / \\
2 .+/ \mathrm{ost} / \\
3 .+/ \mathrm{a} / \\
\\
1 . \mathrm{mn} . \\
1 .+/ \mathrm{n} / \\
2 .+/ \mathrm{t} / \\
3 .+\mathrm{n} /\end{array}$ & $\begin{array}{l}\text { 1. poj. } \\
1 .+/ / / / \\
2 .+/ \partial s t / \\
3 .+/ \mathrm{a} / \\
1 . \mathrm{mn} . \\
1 .+/ \mathrm{n} / \\
2 .+/ \mathrm{t} / / \\
3 .+/ \mathrm{n} /\end{array}$ \\
\hline
\end{tabular}

Krótkim rozważaniom chciałabym również poddać rozwój tematu fleksyjnego w czasie przeszłym trybu przypuszczającego przykładowego czasownika mocnego (swn. nëman, śwn. nëmen, nwn. nehmen) ${ }^{4}$ (por. tabela 14).

\footnotetext{
4 Skróty oznaczają każdorazowo: 'swn' - staro-wysoko-niemiecki; 'śwn' - średnio-wysokoniemiecki; 'nwn' - nowo-wysoko-niemiecki.
} 
Tabela 14. Staro-, średnio- i nowo-wysoko-niemieckie tematy fleksyjne czasu przeszłego trybu przypuszczającego mocnego czasownika swn. nëman, śwn. nëmen i nwn. nehmen ('wziąć, brać') [źródło: oprac. własne]

\begin{tabular}{|l|c|} 
& $\begin{array}{c}\text { Temat fleksyjny } \\
\text { czasu przeszłego } \\
\text { trybu przypuszczającego }\end{array}$ \\
\hline swn. Nëman & /na:mI/ \\
śwn. Nëmen & /næ:mə/ \\
nwn. Nehmen & /ne:mə/ \\
\hline
\end{tabular}

Tematy fleksyjne czasownika wykazują z jednej strony wspólne środki językowe, a z drugiej różnią się od siebie (swn. /na:mI/, śwn. /næ:mə/, nwn. /ne:mə/), przy czym różnice dotyczą elementów samogłoskowych tematów fleksyjnych:

1) opozycja: swn. /a:/ - śwn. /æ:/ - nwn. /\&:/;

2) opozycja: swn. /I/, które realizowane jest jako /i:/ lub /i/ w tzw. niechronionej pozycji (w wygłosie absolutym) - śwn. i nwn. /ə/.

Przejście staro-wysoko-niemieckiego la:/ do średnio-wysoko-niemieckiego /æ:/ określane jest w literaturze odnośnej jako przegłos wtórny [por. m.in. Penzl 1970; Twadell 1970; Szulc 2002: 129n.; Schmidt i in. 2004: 254]. Średnio-wysoko-niemieckie /æ:/ rozwija się natomiast do nowo-wysoko-niemieckiego / $\varepsilon$ :/ [por. Szulc 2002: 233n.], przy czym pochodzenie tej samogłoski jest kontrowersyjne [por. m.in. Moulton 1961; Szulc 1966; Lasatowicz 1980; Sanders 1972; Hinderling 1978]. Zmiana /i:/ lub /i/ do neutralnej głoski shwa /ə/ jest wynikiem osłabienia artykulacji sylab pobocznych [por. m.in. Ehrismann/Ramge 1976: 61; Moser/Wellmann/Wolf 1981: 59-62; Szulc 2002: 134; Schmidt i in. 2004: 256]. Ostatni element tematów fleksyjnych traktowany jest $\mathrm{w}$ literaturze jako: 1) wskaźnik trybu przypuszczającego [swn. /I/: por. Meineke, Schwerdt 2001: 278; nwn. /ə/: por. Jung 1955: 224; Helbig, Buscha 1999: 188; DUDEN. Die Grammatik 2005: 444; Thieroff/Vogel 2009: 22n.; Darski 2010: 146nn.] lub 2) element końcówki fleksyjnej wzgl. samogłoska fleksyjna [swn. /I/: por. Braune, Reiffenstein 2004: 272; śwn. /ə/: por. Paul 2007: 242; nwn. /ə/: por. m.in. Gelhaus 1984: 115, 118n.]. Status elementów samogłoskowych (zarówno stałych, jak i zmiennych) można jednakże jednoznacznie stwierdzić poprzez porównanie tematów fleksyjnych czasu przeszłego trybu przypuszczającego $\mathrm{z}$ ich odpowiednikami w trybie oznajmującym [por. Radojewska 2013]. 


\section{MARTA WOŹNICKA}

Przyjrzyjmy się bliżej wykładnikom syntaktycznym przykładowego czasownika mocnego (swn. nëman, śwn. nëmen, nwn. nehmen) w czasie przeszłym trybu przypuszczającego (por. tabela 15).

Tabela 15. Wykładniki syntaktyczne czasowników swn. nëman, śwn. nëmen i nwn. nehmen ('wziąć, brać') oraz ich tematy fleksyjne dla czasu przeszłego trybu przypuszczającego [źródło: oprac. własne]

\begin{tabular}{|c|c|c|c|}
\hline & temat fleksyjny & liczba pojedyncza & liczba mnoga \\
\hline swn. nëman & /na:mI/ & $\begin{array}{l}\text { 1. /I/ jako /i/ } \\
\text { 2. /I/ jako /i:/+/s/ } \\
\text { 3. /I/ jako /i/ }\end{array}$ & $\begin{array}{l}\text { 1. /I/ jako } / \mathrm{i}: /+/ \mathrm{m} / \\
\text { 2. } / \mathrm{I} / \text { jako } / \mathrm{i}: /+/ \mathrm{t} / \\
\text { 3. } / \mathrm{I} / \text { jako } / \mathrm{i}: /+/ \mathrm{n} /\end{array}$ \\
\hline śwn. nëmen & /næ:mə/ & $\begin{array}{l}\text { 1. } \varnothing \\
\text { 2. }+/ \text { st/ } \\
\text { 3. } \varnothing\end{array}$ & $\begin{array}{l}1 .+/ \mathrm{n} / \\
2 .+/ \mathrm{t} / \\
3 .+/ \mathrm{n} /\end{array}$ \\
\hline nwn. nehmen & /ne:mə/ & $\begin{array}{l}\text { 1. } \varnothing \\
\text { 2. }+/ \mathrm{st} / \\
\text { 3. } \varnothing\end{array}$ & $\begin{array}{l}\text { 1. }+/ \mathrm{n} / \\
2 .+/ \mathrm{t} / \\
\text { 3. }+/ \mathrm{n} /\end{array}$ \\
\hline
\end{tabular}

Wstępnie można stwierdzić, że wykładniki syntaktyczne uległy uproszczeniu. 1. i3. os. 1. poj. wykazują po współczesną niemczyznę tzw. zerowe wykładniki. Charakterystyczny dla 2. os. 1. poj. wykładnik /st/ powstał z enklitycznie dołączonego zaimka osobowego 2. os. 1. poj thu, $d u$ ('ty'). Owe formy zostały dodatkowo wzmocnione przez 2. os. 1. poj. tzw. czasowników Präterito-Präsentien, np. kanst ('możesz') [por. m.in. Moser, Wellmann, Wolf 1981: 202; Meineke, Schwerdt 2001: 276]. 1. os. 1. mn. wykazuje w najstarszych źródłach /m/ jako wykładnik syntaktyczny, który jednak w IX wieku zmienia się w /n/ [por. tamże: 278]. Średnio- i nowo-wysoko-niemiecki zestaw wykładników syntaktycznych nie różni się od siebie.

Zaprezentowana metoda pokazuje, iż możliwe jest bezsprzeczne i dokładne pozyskiwanie wykładników syntaktycznych czasownika oraz jego tematów fleksyjnych, a poprzez to jesteśmy w stanie ustalić wzory koniugacyjne. W ten sposób udowadniam m.in., że model Darskiego ma charakter uniwersalny i może skutecznie być stosowany w badaniach nad morfologią historyczną. Kreatywne stosowanie modelu Darskiego gwarantuje jednak nie tylko właściwy opis badanych form czasownikowych, lecz również przekonującą interpretację przyczyn i mechanizmów ich rozwoju w procesie ewolucji systemu morfologicznego czasownika. 


\section{Bibliografia}

BRAUNE W., 1912: Gotische Grammatik, Tübingen: Max Niemeyer Verlag.

BRAUNE W., 1963: Althochdeutsche Grammatik, Fortgeführt von Karl Helm, 11. Auflage, bearbeitet von Walther Mitzka, Tübingen: Max Niemeyer Verlag.

BRAUNE W., 2004: Gotische Grammatik, 20. Auflage, neu bearbeitet von Frank Heidermanns, Tübingen: Max Niemeyer Verlag.

BRAUNE W., 2004: Althochdeutsche Grammatik I. Laut- und Formenlehre, 15. Auflage, bearbeitet von Ingo Reiffenstein, Tübingen: Max Niemeyer Verlag.

DARSKI J., 1999: Bildung der Verbformen im Standarddeutschen, Tübingen: Stauffenburg.

DARSKI J., 1987: Linguistisches Analysemodell. Definitionen grundlegender grammatischer Begriffe, Poznań: Wydawnictwo Naukowe UAM.

DARSKI J., 2004: Linguistisches Analysemodell. Definitionen grundlegender grammatischer Begriffe. 2., völlig neu bearbeitete und ergänzte Auflage, Poznań: Wydawnictwo Naukowe UAM.

DARSKI J., 2010: Deutsche Grammatik. Ein völlig neuer Ansatz, Frankfurt am Main, Berlin, Bern, Bruxelles, New York, Oxford, Wien: Peter Lang Verlag.

DARSKI J., 2012: Gramatyka niemiecka z uwagami konfrontatywnymi, Poznań: Wydawnictwo Naukowe UAM.

DUDEN: Die Grammatik 2005, 7., völlig neu erarbeitete und erweiterte Auflage, herausgeben von der Dudenredaktion. Bearbeitet von Eisenberg P., Peters J., Gallmann P, Fabricius-Hansen C., Nübling D., Barz I., Fritz T.A., Fiehler R. Mannheim, Leipzig, Wien, Zürich: Dudenverlag.

EHRISMANN O., RAMGE H., 1976: Mittelhochdeutsch. Eine Einführung in das Studium der deutschen Sprachgeschichte, Tübingen: Max Niemeyer Verlag.

GABELENTZ VON DER H., LOEBE, J., 1843-1846: Ulfilas: Veteris et Novi Testamenti versionis gothicae fragmenta quae supersunt ad fidem codd. castigata, latinate donata, adnotatione critica instructa: cum glossario et grammatica linguae gothicae coniunctis, Bde. 1-2, Leipzig: Brockhaus.

GElHAUS H., 1984: Die Wortarten, Sonderdruck aus der Duden-Grammatik, Mannheim, Leipzig, Wien, Zürich: Dudenverlag.

Helbig G., Buscha J., 1999: Deutsche Grammatik. Ein Handbuch für Ausländerunterricht, Leipzig, Berlin, München, Wien, Zürich, New York: Enzyklopädie Langenscheidt.

HENNINGS T., 2001: Einführung in das Mittelhochdeutsche, Berlin, New York: Walter de Gruyter. 


\section{MARTA WOŹNICKA}

HiNDERLING R., 1978: Das Phonem nhd. /ä / im Lichte der Sprachgeschichte, in: Fimfchustin: fone fimfchur tim. Festschrift für Stefan Sonderegger zum 50. Geburtstag am 28. Juni 1977, eds. R. Hinderling, V. Weibel, Bayereuth: Univ., Lehrstuhl für Deutsche Sprachwissenschaft, s. 29-61.

JUNG W., 1955: Kleine Grammatik der deutschen Sprache. Satz- und Beziehungslehre, Leipzig: VEB Bibliographisches Institut.

Kotin M. L., 2008: Das „Linguistische Analysemodell” von Józef Darski im sprachhistorischen bzw. sprachtypologischen Diskurs, in: Terra grammatica: Ideen - Methoden - Modelle: Festschrift für Józef Darski zum 65. Geburtstag, eds. M.L. Kotin, B. Mikołajczyk, Frankfurt am Main, Berlin, Bern, Bruxelles, New York, Oxford: Peter Lang Verlag, s. 167-177.

Kotin M. L., 2012: Gotisch: Im (diachronischen und typologischen) Vergleich, Heidelberg: Universitätsverlag WINTER.

LASATOWICZ K., 1980: Die deutschen e-Laute historisch betrachtet, „Neophilologica" 1, Katowice: Wydawnictwo Uniwersytetu Śląskiego, s. 131-140.

MEINEKE E., SCHWERDT J., 2001: Einführung in das Althochdeutsche, Paderborn, München, Wien, Zürich: Ferdinand Schöningh.

Moulton W. G., 1961: Zur Geschichte des deutschen Vokalsystems, „Beiträge zur Geschichte der deutschen Sprache und Literatur" , Tübingen: Niemeyer, s. 1-35.

MOSER H., WellmanN H., WOLF N. R., 1981: Geschichte der deutschen Sprache. Band 1: Althochdeutsch - Mittelhochdeutsch, Heidelberg: Quelle \& Meyer.

PAul H., 2007: Mittelhochdeutsche Grammatik, 25. Auflage, neu bearbeitet von Thomas Klein, Hans-Joachim Solms, Klaus-Peter Wegera. Mit einer Syntax von Ingeborg Schöbler, neubearbeitet und erweitert von Heinz-Peter Prell, Tübingen: Max Niemeyer Verlag.

PENZL H., 1949/1970: Umlaut und Sekundärumlaut im Althochdeutschen, in: Vorschläge für eine strukturale Grammatik des Deutschen, ed. H. Steger, Darmstadt: Wissenschaftliche Buchgesellschaft, s. 545-574.

RADOJEWSKA M., 2013: Die Markierung des Konjunktivs vom Gotischen bis zum Neuhochdeutschen, „Kwartalnik Neofilologiczny”, z. 1, Warszawa: Wydział I Nauk Humanistycznych i Społecznych PAN, s. 94-114.

SANDERS W., 1972: Hochdeutsch /ä/ - ,Ghostphonem' oder Sprachphänomen? "Zeitschrift für Dialektologie und Linguistik" 39, Wiesbaden: Francke Steiner Verlag, s. 37-58. 
SCHMIDT W., 2004: Geschichte der deutschen Sprache. Ein Lehrbuch für das germanistische Studium, Erarbeitet unter der Leitung von Helmut Langner und Norbert Richard Wolf, 9., verbesserte Auflage, Stuttgart: S. Hirzel Verlag. SzULC A., 1966: The phonemic status of NHG [E ]], „Kwartalnik Neofilologiczny“ 13, Warszawa: Państwowe Wydawnictwo Naukowe, s. 425-429.

SZULC A., 2002: Geschichte des standarddeutschen Lautsystems, Wien: Verlag Edition Praesens.

THIEROFF R., VOGEL P. M., 2009: Flexion, Heidelberg: Universitätsverlag WINTER.

\section{Zum Wandel im Konjugationsparadigma vom Gotischen bis zum Neuhochdeutschen (Zusammenfassung)}

Der Autor des „Linguistischen Analysemodells“ [1987; 2004], Józef Darski, hat in seinen Publikationen mehrmals betont, dass sein Analysemodell ausschließlich synchron konzipiert ist, d.h. seine Methoden beziehen sich auf einen gegebenen synchronen Querschnitt einer gegebenen Sprache. In seinen Ausführungen strebt Darski nach Präzision, die ihm einerseits die Präsentation seines Modells am Beispiel gewählter europäischer Sprachen, u.a. des Deutschen, Englischen, Französischen und Polnischen ermöglicht, andererseits erlaubt sie ihm den Abstraktionsgrad zu erreichen, der die günstige Anwendung des Modells zur Untersuchung anderer Sprachen gewährleistet. Michail L. Kotin [2008; 2012] hat dagegen bewiesen, dass Darskis Überlegungen auch aus der Perspektive des Sprachwandels betrachtet werden können.

Im Artikel werden die Probleme der Beschreibung von synthetischen verbalen Formen im Gotischen, Alt-, Mittel- und Neuhochdeutschen sowohl synchron, d.h. getrennt für das Gotische und jede einzelne historische Etappe des Deutschen, als auch diachron, d.h. im historischen Vergleich, der entsprechende Sprachwandelerscheinungen sowie ihre Rolle bei der Gestaltung des gegenwärtigen Verbalparadigmas berücksichtigt, behandelt. Die Analyse wird anhand des Modells von Józef Darski durchgeführt, wobei sie um diachronische Aspekte erweitert wird. Da im Rahmen dieses Beitrags unmöglich ist, die Analyse des ganzen historischen Sprachmaterials vorzunehmen, wurden zu diesem Zweck Mikroparadigmen des Indikativs sowie Konjunktivs starker wie schwacher Verben gewählt. 